\title{
Monitoring the glacier changes in the Muztag Ata and Konggur mountains, east Pamirs, based on Chinese Glacier Inventory and recent satellite imagery
}

\author{
SHANGGUAN Donghui, ${ }^{1}$ LIU Shiyin, ${ }^{1,2}$ DING Yongjian, ${ }^{1}$ DING Lianfu, ${ }^{1}$ \\ XIONG Libing, ${ }^{3}$ CAI Dihua, ${ }^{3}$ LI Gang, ${ }^{1}$ LU Anxin, ${ }^{1}$ ZHANG Shiqiang, ${ }^{1}$ ZHANG Yong ${ }^{1}$
}

${ }^{1}$ Key Laboratory of Cryosphere and Environment, Cold and Arid Regions Environmental and Engineering Research Institute, Chinese Academy of Sciences, 260 Donggang West Road, Lanzhou 730000, China

E-mail:dhguan@Izb.ac.cn

${ }^{2}$ Tibetan Plateau Research Institute, Chinese Academy of Sciences, Beijing 100029, China

${ }^{3}$ Lanzhou University, Lanzhou 730000, China

\begin{abstract}
Glaciers in the Muztag Ata and Konggur mountains of the eastern Pamir plateau, northwestern China, have been monitored by applying aerial photo stereo models $(1962 / 66)$ and Landsat TM (1990) and ETM+ (1999) images, all of which have been compared in order to detect areal and frontal changes through the past four decades. The mean frontal retreat of glaciers in the Muztag Ata and Konggur mountains increased from $6.0 \mathrm{~m} \mathrm{a}^{-1}$ between 1962/66 and 1990 to $11.2 \mathrm{~m} \mathrm{a}^{-1}$ between 1990 and 1999, with an overall glacier length reduction of $9.9 \%$ for the whole study period. The glacier area has decreased by $7.9 \%$, mainly due to changes observed in the most recent period (1990-99), when the annual area loss almost tripled to $1.01 \mathrm{~km}^{2} \mathrm{a}^{-1}$. Based on meteorological data from Taxkogan station since 1957, we conclude that climate change, particularly the rise in summer temperature after 1994 , is the main forcing factor in glacier shrinkage.
\end{abstract}

\section{INTRODUCTION}

Changes in mountain glaciers are one of the natural indicators of climate change (Oerlemans, 1994). With global warming, the glaciers in middle and low latitudes have retreated continually and glacier mass balance has been continuously negative since the 1990s (e.g. Yao and others, 2004). Several investigators have shown that glacier shrinkage can contribute substantially to rising sea level (e.g. Zuo and Oerlemans, 1997; Van de Wal and Wild, 2001). Glaciers have an important role in climate change, sea-level rise and flood hazards. This is why investigation of glacier mass-balance and glacier area fluctuations is an important component of the Global Climate Observing System (Haeberli and others, 2000). The Global Land Ice Measurements from Space (GLIMS) project was carried out to monitor land glacier changes using Landsat Enhanced Thematic Mapper Plus (ETM+)/Thematic Mapper (TM), Advanced Spaceborne Thermal Emission and Reflection Radiometer (ASTER) and other remote-sensing images (Kieffer and others, 2000; Kääb and others, 2002; Paul and others, 2002b).

The Chinese Glacier Inventory (CGI), concluded in 2002 (Mi and others, 2002), was a significant step in integrating knowledge of glaciers in China, and forms the key database for further studies on regional glacier fluctuations, their responses to climate change and their influence on water resource variations. A pronounced atmospheric warming of $0.7^{\circ} \mathrm{C}$ occurred over western China during the past 50 years (D. Li and others, 2003), with a likely climate shift from warm, dry to warm, wet conditions in northwestern China (Shi and others, 2002). Glacier retreat prevailed in recent decades throughout China, as shown by field observations and satellite remote-sensing monitoring (Ren and others, 1998; Zhen and others, 1998; He and others, 2003; Li and others, 2003; Liu and others, 2003; Yang and others, 2003;
Jin and others, 2004). However, there are still several regional gaps where glacier behavior is presently unknown. In order to characterize the response of glaciers to climate change in different regions with various climatic settings, it is necessary to extend our monitoring of glaciers to regions like the Muztag Ata and Konggur mountains in the eastern Pamirs. This research is also motivated by the fact that water resources are vital to society and economic development in this drought-prone inland region. Glacier runoff here plays an important role as a source of water for one of the key tributaries of the Tarim river, the Kaxgar river, which supports daily life, agriculture, livestock and industry in the city of Kaxgar. The glacier changes in the Tarim basin over the past several decades are estimated (Fig. 1) by comparing the photogrammetrically derived CGI with Landsat TM/ETM+ satellite images acquired more recently. The results of this study will assist investigations of hydrological change, and regional water-resource management.

\section{STUDY AREA}

The Muztag Ata and Konggur mountains are located on the eastern Pamir plateau, China $\left(38-39^{\circ} \mathrm{N}, 74^{\circ} 40^{\prime}-75^{\circ} 40^{\prime} \mathrm{E}\right)$. They range in elevation from about $3000 \mathrm{~m}$ a.s.l. to a maximum of 7546 and 7719 ma.s.l. at the two summits, respectively. Several valley glaciers descend from the ice caps, most of them with snowline elevations of 5200$5700 \mathrm{~m}$ a.s.l. and terminus positions at 3900-4900 ma.s.I., according to the CGI (Yang and An, 1989; Liu and others, 2001). Glaciers in the study region feed three rivers: the Taxkogan river, which is a tributary of the Yarkant river, and two tributaries of the Kaxgar river, the Kusan and Gezhe rivers (Fig. 1).

These glaciers are of an extremely continental type, with one of the coldest environments in low- and mid-latitude 


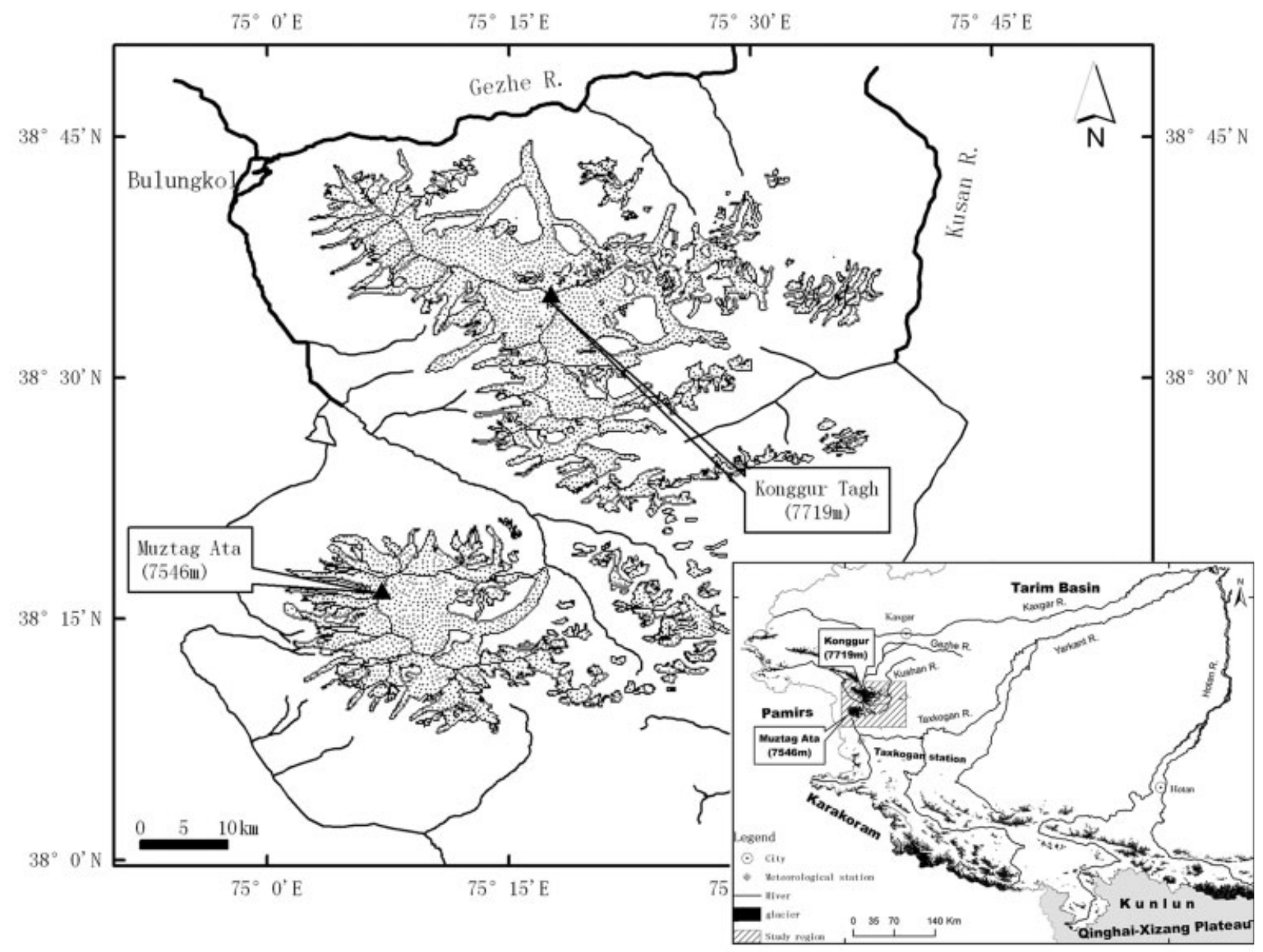

Fig. 1. Location map of the study region in the Muztag Ata and Konggur mountains. Glacier masks (black) were derived from the digitized CGl of 1962/66.

regions (Zhang, 1980; Su and others, 1989; Wu and others, 2003; Li and others, 2004) and one of the driest glacierized areas in China. The data at Taxkogan meteorological station $\left(37^{\circ} 46^{\prime} \mathrm{N}, 75^{\circ} 14^{\prime} \mathrm{E}\right.$; 3090.9 m.a.s.l.) show that annual precipitation remains below $70 \mathrm{~mm}$ and mean summer temperature (June-August) is as high as $15.1^{\circ} \mathrm{C}$. It is estimated that monthly mean air temperatures can be higher than $0^{\circ} \mathrm{C}$ over glacier terminus areas during the warm season (May-September), so intensive ablation may occur in June-August.

According to the CGl, there are more than 302 glaciers in the Muztag Ata and Konggur mountains, covering a total area of $1067.24 \mathrm{~km}^{2}$ (Yang and An, 1989; Liu and others,
2001). The majority are small glaciers, as shown in Figure 2 $\left(53.5 \%\right.$ of them are $\left.<1 \mathrm{~km}^{2}\right)$, but because there are some larger glaciers the mean glacier area is $2.82 \mathrm{~km}^{2}$.

\section{METHODS AND DATA SOURCES}

The data sources used in this study are listed in Table 1. Glacier outlines from the CGI were interpreted and measured by stereophotogrammetry from aerial photographs at a scale of $1: 46000 / 50000$ taken during 1962/66. They were transferred to $1: 100000$ topographic maps in the Universal Transverse Mercator (UTM) coordinate system referenced to the World Geodetic System 1984 (WGS84). Finally, the

Table 1. Data sources used in this study

\begin{tabular}{|c|c|c|c|c|c|c|}
\hline Image & Path/row & $\begin{array}{l}\text { Resolution } \\
\text { or scale } \\
\mathrm{m}\end{array}$ & Date & Quality & $\begin{array}{l}\text { rmse } \\
\mathrm{m}\end{array}$ & Source \\
\hline Landsat 5 TM & $149 / 33$ & 30 & 6 July 1990 & Cloud ( $2 \%)$ and very little snow & 39.2 & NASA \\
\hline Landsat 5 TM & $149 / 34$ & 30 & 6 July 1990 & Cloud ( $2 \%)$ and very little snow & 44.9 & \\
\hline Landsat 7 ETM+ & $149 / 33$ & 15 & 25 Sept. 1999 & Cloud-free & 31.5 & \\
\hline Landsat 7 ETM+ & $149 / 34$ & 15 & 25 Sept. 1999 & Cloud $(6 \%)$ & 34.5 & \\
\hline Topographic map & - & $1: 100000$ & 1981 & - & & Chinese military geodetic service \\
\hline CGI & - & $1: 100000$ & $1962 / 66$ & - & & Aerial photographs \\
\hline DEM & - & $1: 100000$ & 1981 & - & & Topographic maps \\
\hline
\end{tabular}




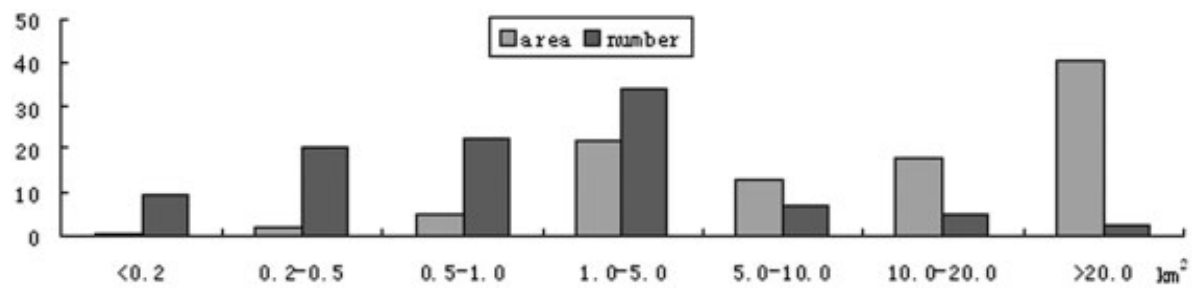

Fig. 2. Frequency of glacier area and number according to different area classes. The numerous glaciers in the $1-5 \mathrm{~km}^{2}$ range cover about $21.3 \%$ of the total glacierized area in the Muztag Ata and Konggur mountains.

glacier outlines were digitized as Geographic Information System (GIS)-based vector files (total 302 glaciers) for further processing. The 1981 digital elevation model (DEM) was produced by digitizing the $40 \mathrm{~m}$ interval contours and spot heights from the same topographic maps, using ArcView software. Two Landsat TM images and two Landsat ETM+ images with almost no cloud and snow cover were chosen and used. Composite images from bands 5, 4 and $3(30 \mathrm{~m}$ resolution) were produced first and merged with the band 8 (15 $\mathrm{m}$ resolution) Landsat ETM+ image. These images were orthorectified with the Orthobase Generic Pushbroom package using the 1:100000 topographic maps and the 1981 DEM. Twenty independent verification points (Dwyer, 1995; Zhen and others, 1998) were selected from each image in order to check the accuracy of co-registration. The result showed that the residual root-mean-square error (rmse) of all images was $<44.9 \mathrm{~m}$ (Table 1 ).

Different methods have been suggested for image classification to extract glacier borders (Paul, 2000; Zhang and others, 2001; Paul and others, 2002b), with image ratio and supervised classification the most commonly used. Compared with other methods, the ratio of TM3/TM5 (Rott, 1994) with a threshold larger than 2.1 gives the best result in this work because of the influence of slope shadows. Due to the limitations of the method employed (Paul and others, 2002a), misidentification is frequent, for instance, on seasonal snowpatches adjacent to glaciers or on debriscovered surfaces which are difficult to distinguish from bedrock owing to their similar spectral properties. In these cases, visual interpretation was applied, combined with multispectral satellite images and the 1981 DEM (Paul and others, 2004a). Glacier extents in 1990 and 1999 were obtained by these methods. The error in area for most glaciers was generally $<1 \%$ for both Landsat ETM+ and TM. Unfortunately, 27 glaciers of $<0.2 \mathrm{~km}^{2}$, derived from Landsat
TM in 1990, had to be excluded because of the limited spatial resolution of Landsat TM and the geometric correction error of $6-9 \%$ of glacier area (Paul and others, 2002a). In addition, two cloud- and three debris-covered glaciers (total area $229.03 \mathrm{~km}^{2}$ ) were also excluded since it was difficult to determine where the glacier boundary was. Thus, the first results of glacier changes derived from the 1962/66 CGI and observed from 1990 and 1999 satellite images were computed for a sample of about 297 glaciers of the Muztag Ata and Konggur mountains.

\section{RESULTS}

\section{Glacier area changes}

Glacier area has decreased significantly between 1962/66 and 1999 in the Muztag Ata and Konggur mountains (Table 2), with a total area loss of $66.02 \mathrm{~km}^{2}$, which is equivalent to $7.9 \%$ of the original area in the early $1960 \mathrm{~s}$. Area reduction of glaciers of $1-5 \mathrm{~km}^{2}$ contributes $44.6 \%$ of the total area loss. The mean size of glaciers in the Muztag Ata and Konggur mountains decreased from $2.82 \mathrm{~km}^{2}$ to $2.63 \mathrm{~km}^{2}$ between 1962/66 and 1999. The rate of area reduction was $1.01 \mathrm{~km}^{2} \mathrm{a}^{-1}$ between 1962 and 1990, but increased more than four times to $4.26 \mathrm{~km}^{2} \mathrm{a}^{-1}$ in the period 1990-99, clearly showing that glacier retreat in the region is accelerating.

Larger glaciers have lost more total area than small glaciers (Fig. 3a). As for the relative changes of glaciers of different sizes, small glaciers usually show a higher percentage area reduction than large glaciers (Fig. 3b), and thus greater sensitivity to climate change. The few exceptions to this area-loss result are glaciers within some of the size classes that showed an area increase throughout the period (Fig. 3b), but three glaciers (World Glacier Monitoring

Table 2. Summary of glacier area data in the Muztag Ata and Konggur mountains according to area class

\begin{tabular}{|c|c|c|c|c|c|c|c|c|c|}
\hline \multirow[t]{2}{*}{ Area class } & \multirow[t]{3}{*}{ Number } & \multicolumn{3}{|c|}{ Mean size } & \multicolumn{3}{|c|}{ Total area } & \multicolumn{2}{|c|}{ Area change } \\
\hline & & $1962 / 66$ & 1990 & 1999 & $1962 / 66$ & 1990 & 1999 & 1962-90 & 1990-99 \\
\hline $\mathrm{km}^{2}$ & & $\mathrm{~km}^{2}$ & $\mathrm{~km}^{2}$ & $\mathrm{~km}^{2}$ & $\mathrm{~km}^{2}$ & $\mathrm{~km}^{2}$ & $\mathrm{~km}^{2}$ & $\mathrm{~km}^{2} \mathrm{a}^{-1}$ & $\mathrm{~km}^{2} \mathrm{a}^{-1}$ \\
\hline$<0.2$ & 27 & 0.13 & - & 0.11 & 3.41 & $3.41^{*}$ & 2.9 & - & -0.06 \\
\hline $0.21-0.5$ & $64 / 62$ & 0.37 & 0.34 & 0.29 & 23.56 & 21.87 & 18.05 & -0.06 & -0.42 \\
\hline $1.01-5.0$ & 99 & 2.30 & 2.14 & 2.00 & 227.27 & 212.08 & 197.82 & -0.54 & -1.58 \\
\hline $5.01-10.0$ & 20 & 6.48 & 6.35 & 6.24 & 129.54 & 127.01 & 124.7 & -0.09 & -0.33 \\
\hline 10.01-20.0 & 14 & 12.80 & 12.53 & 12.10 & 179.23 & 175.42 & 169.43 & -0.14 & -0.67 \\
\hline$>20.01$ & 5 & 45.15 & 44.78 & 43.45 & 225.74 & 223.94 & 217.24 & -0.06 & -0.74 \\
\hline All classes & $297 / 294$ & 2.82 & 2.73 & 2.63 & 838.21 & 809.88 & 772.19 & -1.01 & -4.26 \\
\hline
\end{tabular}



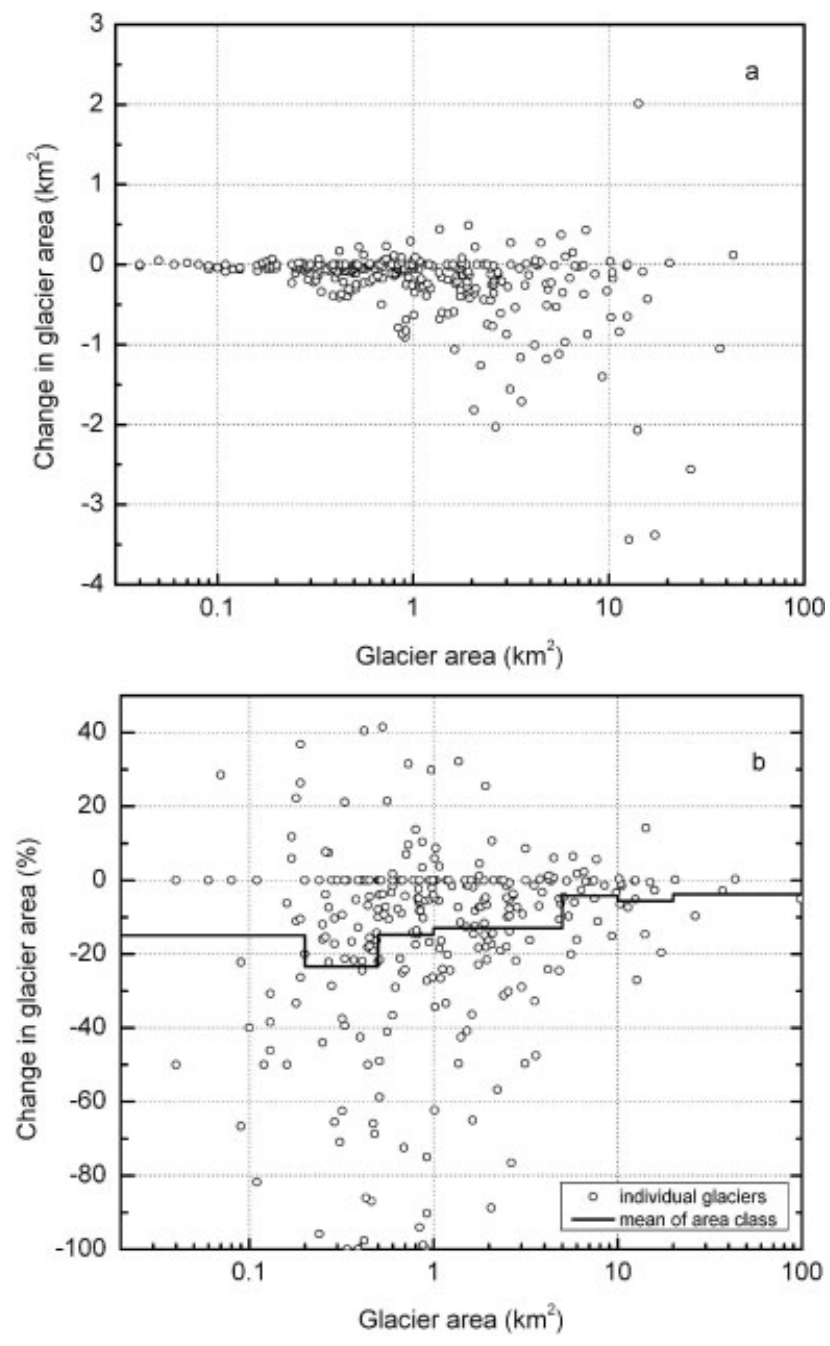

Fig. 3. Net (a) and relative (b) glacier area changes, 1962-99. The changes are averaged for the area classes shown in Figure 2 (bold line). The smaller the glaciers, the higher their average percentage area loss. Two exceptions to the area loss are found in glaciers $<0.2 \mathrm{~km}^{2}$ and in the $5-10 \mathrm{~km}^{2}$ range.

Service IDs CN5Y663B17, CN5Y662D25 and CN5Y662F1) disappeared. One reason that glaciers $<0.2 \mathrm{~km}^{2}$ and $5-10 \mathrm{~km}^{2}$ in size showed relatively little change may be the offset effect of advancing glaciers.

A comparison with glacier changes in other regions of China is presented in Table 3. Glacier changes in the Muztag
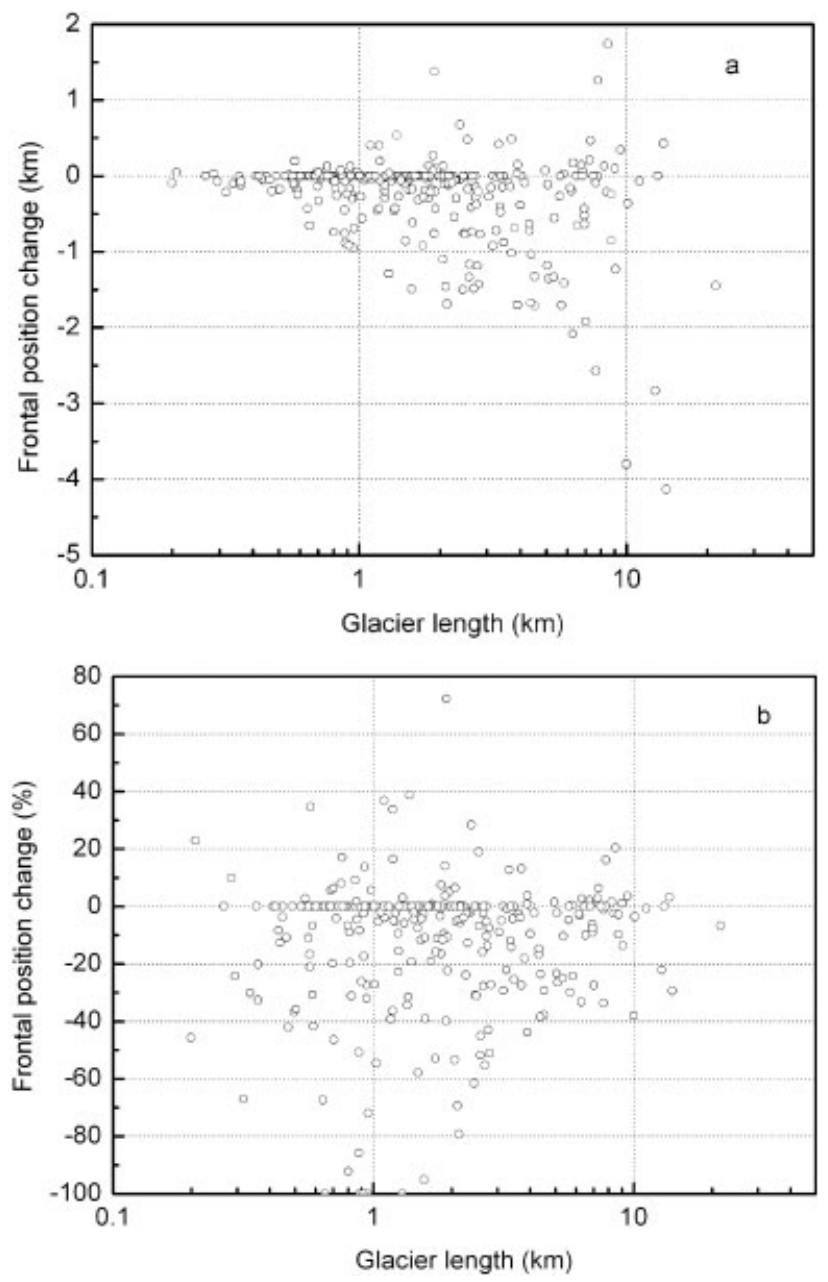

Fig. 4. Net (a) and relative (b) glacier front position changes, 1962-99.

Ata and Konggur mountains appear larger than in other extreme continental-type regions (Yang and others, 2003; Liu and others, 2004) and parts of subcontinental-type regions in China. However, they are smaller than in maritime-type and other parts of subcontinental-type regions (He and others, 2003; Z. Li and others, 2003; Yang and others, 2003). These results suggest that glaciers in the Muztag Ata and Konggur mountains have disintegrated rapidly since the 1960 s.

Table 3. Comparison of glacier changes in China

\begin{tabular}{|c|c|c|c|c|c|c|}
\hline \multirow[t]{2}{*}{ Region } & \multirow[t]{2}{*}{ Glacier type } & \multirow[t]{2}{*}{ Time-span } & \multirow[t]{2}{*}{ Glacier count } & \multicolumn{2}{|c|}{ Area change } & \multirow[t]{2}{*}{ Data source } \\
\hline & & & & $\mathrm{km}^{2}$ & $\%$ & \\
\hline Yulong glacier No. 1 & Moraine & 19th century-2002 & 1 & & -40 & He and others (2003) \\
\hline A'nyêmagên & Subcontinental & $1966-2000$ & 58 & -21.7 & -17.0 & Yang and others (2003) \\
\hline Ürümqi glacier No. 1 & Subcontinental & 1959-2000 & 1 & 0.22 & -11.1 & Li and others (2004) \\
\hline Pengqu basin & Subcontinental & 1970-2000/01 & 99 & -2.67 & -9.0 & Jin and others (2004) \\
\hline Nyainqen Tanglha MTS & Subcontinental & 1970-2000 & 870 & -52.2 & -5.7 & This study \\
\hline Karakoram & Subcontinental & 1969-99 & 565 & -111.1 & -4.1 & This study \\
\hline East Pamirs & Extreme continental & 1962/66-1999 & 297 & -66.02 & -7.9 & This study \\
\hline Geladandong & Extreme continental & 1969-2000 & 753 & -14.91 & -1.7 & Yang and others (2003) \\
\hline Xingqingfeng glacier & Extreme continental & $1973-2000$ & 88 & -6.79 & -1.6 & Liu and others (2004) \\
\hline
\end{tabular}




\section{Glacier frontal changes}

In general, an average $9.9 \%$ glacier front retreat was detected during the 1962/66-1999 period. Figure 4a and b, respectively, show the absolute and relative length changes of individual glaciers against their lengths in the early 1960s. Comparisons of glacier terminus positions in the last few decades indicate that 167 glaciers were retreating, about 40 were advancing and that changes of about 90 glaciers cannot be determined. Similar to the change in glacier area, glaciers experienced a slow retreat in length at a mean rate of $6.0 \mathrm{~m} \mathrm{a}^{-1}$ between 1962 and 1990 and a much more rapid retreat of $11.2 \mathrm{~m} \mathrm{a}^{-1}$ in the $1990 \mathrm{~s}$. Thus, in the 1990s the glaciers shortened 1.9 times more quickly than in the approximately 30 years before 1990 .

As most values are above the diagonal line, relative change in area is larger than the corresponding change in length for most of the glaciers during the time-span under consideration (Fig. 5). It is also worth noting that the change in glacier area is not always synchronous with the change in glacier length. Some retreating glaciers expanded in area due to the increase in accumulation area but decreased at the terminus, and the opposite for advancing glaciers. This implies that change can occur on any part of a glacier. The ratio of mean retreat rate of glacier fronts during the 199099 period to that during 1962-90 (1.9) is less than the ratio (4.0) for glacier area. However, length changes (9.9\%) are greater than area changes $(7.9 \%)$ when all the sampled glaciers are considered.

\section{TEMPERATURE, PRECIPITATION AND GLACIER CHANGES}

There are only a few meteorological stations, with relatively short-term instrumental records, in western China, especially in the mountain regions. The Taxkogan meteorological station is the only meteorological station on the Pamir plateau located above $3000 \mathrm{~m}$ a.s.l. (Fig. 1). The station has been operating since 1957. The summer temperature and annual precipitation at the Taxkogan station from 1957 to 2000 are shown in Figure 6. The summer temperature rose

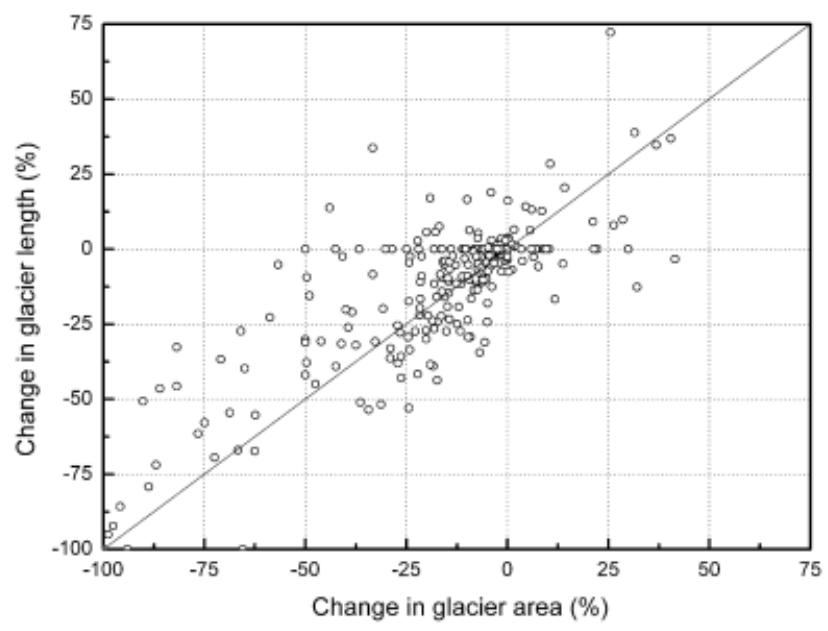

Fig. 5. Glacier area changes vs frontal changes (in \%), 1962-99.

by $0.7^{\circ} \mathrm{C}$ between 1957 and 2000 , and the winter temperature, not shown, did not rise appreciably. This time-span included three cold periods: 1961-68, 1973-77 and 198593. Annual precipitation has increased slightly in the last four decades, which represents favorable climatic conditions for glaciers. Therefore, we believe that glacier retreat during the past 40 years can be attributed mainly to air-temperature rise in the Muztag Ata and Konggur mountains. We also expect that a sharp retreat of glaciers in the region may occur in the future due to the warming in the most recent decade. However, some glacier advances might be a response to the three periods of cooling and the increase of annual precipitation, along with the glacial dynamics responses of individual glaciers.

The study of Pu and others (2003) verifies that surface ablation on an occasionally observed glacier was intensified by atmospheric warming from the 1960s/80s to 2001 in the Muztag Ata mountain region. Hydrological analysis gives the result that glaciers in the Kangxiwa river valley headwaters of the Kaxgar river have been losing mass at a rate of $123.5 \mathrm{~mm} \mathrm{a}^{-1}$ (Shen and others, 1997).

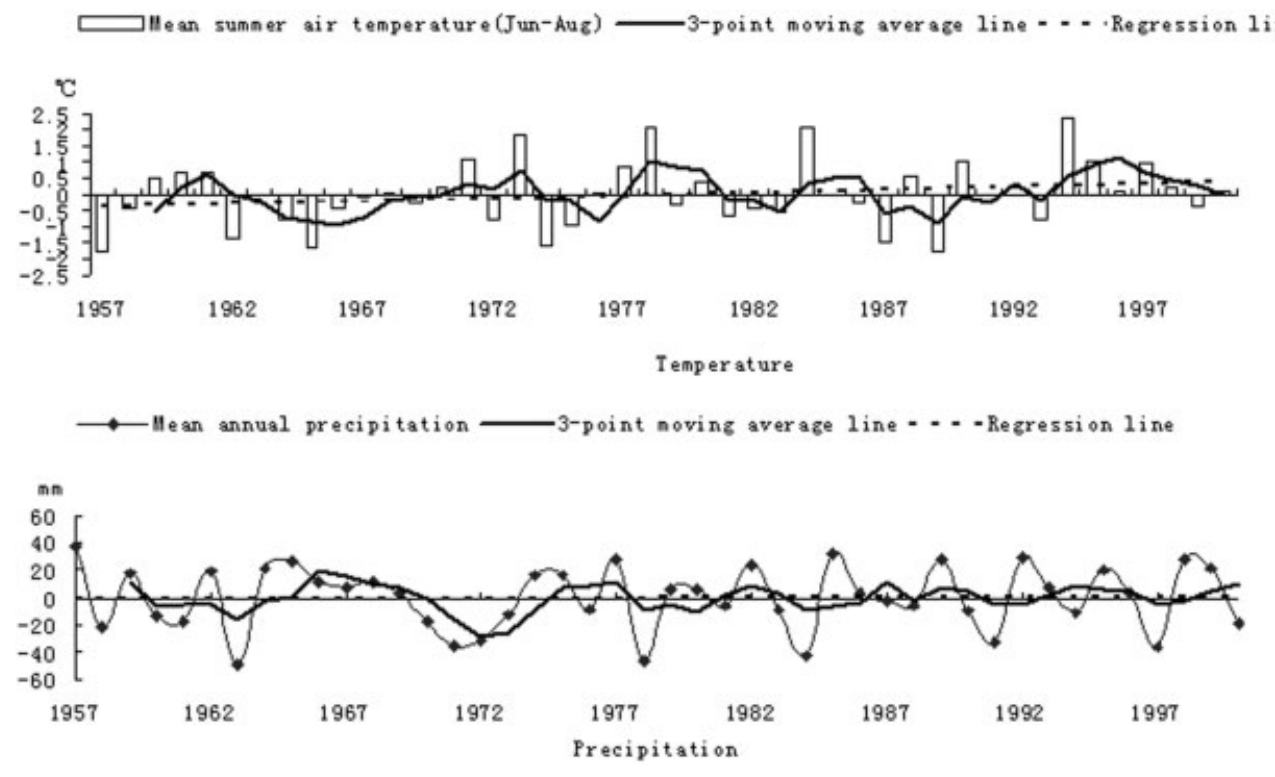

Fig. 6. Changes in mean summer air temperature (June-August) and mean annual precipitation at Taxkogan meteorological station. 


\section{CONCLUSION}

The present study supports previous findings (e.g. Khromova and others, 2003; Paul and others, 2004b) that cold, highmountain glaciers have been disintegrating rapidly since the 1970s. Our measurements show that glacier areas and frontal positions have decreased by $7.9 \%$ and $9.9 \%$, respectively, between 1962 and 1999 in the Muztag Ata and Konggur mountains. Furthermore, a drastic acceleration of retreat since the 1990s is found. The mean frontal retreat of glaciers increased from $6.0 \mathrm{~m} \mathrm{a}^{-1}$ in the $1962 / 66-1990$ period to $11.2 \mathrm{~m} \mathrm{a}^{-1}$ in 1990-99, and the area shrinkage of glaciers in 1990-99 increased about three times, to $1.01 \mathrm{~km}^{2} \mathrm{a}^{-1}$, from the annual rate in 1962/66-1990. These accelerations are consistent with climate warming during recent decades.

Changes in glacier frontal positions and glacier area are easily observed phenomena with which to study the impact of climate change (Oerlemans, 1994) and its influence on water resources in arid regions (Yao and others, 2004). Glacier frontal changes are strongly enhanced but indirect, filtered and delayed signals of climate change (Oerlemans, 2001). They can be used to show that the few direct studies of mass-balance variability are representative (Hoelzle and others, 2003) and to reconstruct historical climate variability (Oerlemans, 1994). The instrumental record at the Taxkogan meteorological station, which is $>50 \mathrm{~km}$ away from the glacierized region, is not adequate to analyze climate changes in the Muztag Ata and Konggur mountains in detail. Nevertheless, glacier retreat is occurring and this has accelerated in the 1990s. Furthermore, glacier ice mass loss since the 1980s has increased the magnitude and frequency of flash floods in the Gezhe river because ablation of the glacier surface accelerated as a consequence of atmospheric warming (Y. Li and others, 2003). Recently initiated massbalance measurements and ice-core records from the Muztag Ata and Konggur mountains will assist detection of the climate-glacier-meltwater interaction.

Although glacier retreat in recent decades such as observed in the Muztag Aga and Konggur mountains is a response to climate fluctuations, other factors also cause the glaciers to change: glacier terrain, kinematics, dimensions, the sensitivity of different types of glaciers to climate change, etc. Owing to the dynamic response, glacier fluctuations usually lag climate change by 5-20 years for medium-sized glaciers (Ding, 1995; Liu and others, 1999). This characteristic means that some glaciers advance under conditions of regional atmospheric warming. As for the glacier dimensions, the narrow lowest parts and wide higher, ablation, area on most glaciers also influence the ratio of glacier area and glacier length variations.

\section{ACKNOWLEDGEMENTS}

Special appreciation is due to $\mathrm{Pu}$ Jianchen, Wu Guangjian and Duan Keqin for their helpful suggestions on this paper and to Liu Chaohai for his careful review. We are grateful to the reviewers and the scientific editor for suggestions and comments that significantly improved the paper. We thank GLIMS for maintaining parts of the satellite data and software through the EROS (Earth Resources Observation Systems) Data Center. This research is supported financially by the National Natural Science Foundation of China (grants 90202013 and 40371026) and the Chinese Academy of Sciences (grant KZCX3-SW-345).

\section{REFERENCES}

Ding, Y. 1995. Response of global glacier fluctuations to climatic change in recent 40 years. Science in China, Ser. B, 25(10), 1093-1098. [In Chinese.]

Dwyer, J.L. 1995. Mapping tidewater glacier dynamics in East Greenland using Landsat data. J. Glaciol., 41(139), 584-595.

Haeberli, W., J. Cihlar and R.G. Barry. 2000. Glacier monitoring within the Global Climate Observing System. Ann. Glaciol., 31, 241-246.

He, Y., J. Gu and D. Zhang. 2003. Correspondence. What is the major reason for glacier retreat on Yulong mountain, China? J. Glaciol., 49(165), 325-326.

Hoelzle, M., W. Haeberli, M. Dischl and W. Peschke. 2003. Secular glacier mass balances derived from cumulative glacier length changes. Global Planet. Change, 36(4), 295-306.

Jin, R., T. Che, X. Li and L. Wu. 2004. Glacier variation in the Pumqu Basin derived from remote sensing data and GIS technique. J. Glaciol. Geocryol., 26(3), 261-266. [In Chinese.]

Kääb, A., F. Paul, M. Maisch, M. Hoelzle and W. Haeberli. 2002. The new remote-sensing-derived Swiss glacier inventory: II. First results. Ann. Glaciol., 34, 362-366.

Khromova, T.E., M.B. Dyurgerov and R.G. Barry. 2003. Latetwentieth century changes in glacier extent in the Ak-shirak Range, Central Asia, determined from historical data and ASTER imagery. Geophys. Res. Lett., 30(16), 1863. (10.1029/ 2003GL017233.)

Kieffer, H. and 41 others. 2000. New eyes in the sky measure glaciers and ice sheets. EOS Trans. AGU, 81(24), 265, 270-271.

$\mathrm{Li}, \mathrm{D}$. and 7 others. 2003. The present facts and the future tendency of the climate change in Northwest China. J. Glaciol. Geocryol., 25(2), 135-142. [In Chinese.]

Li, Y., H. Li and L. Wang. 2003. Analysis on the hydrology and water resource of Gez River in Karakorum Mountain. Arid Zone Research, 20(4), 272-274. [In Chinese.]

Li, Z., T. Han, Z. Jin, H. Yang and K. Jiao. 2003. A summary of 40 year observed variation facts of climate and Glacier No. 1 at the headwater of Ürümqi River, Tianshan, China. J. Glaciol. Geocryol., 25(2), 117-123. [In Chinese with English abstract.]

Li, Z., T. Yao, L. Tian, B. Xu, G. Wu and G. Zhu. 2004. Borehole temperature at the ice-core drilling site in the Muztag Ata glacier, East Pamirs. J. Glaciol. Geocryol., 25(6), 280-284. [In Chinese.]

Liu, C., Z. Wang and L. Ding, eds. 2001. Glacier Inventory of China. Revised edition. Pamirs (Drainage basins of Kaxgar River and others). Lanzhou, Gansu Culture Publishing House. [In Chinese.]

Liu, S., N. Wang, Y. Ding and Z. Xie. 1999. On the characteristics of glacier fluctuations during the last 30 years in the Urumqi River basin and the estimation of temperature rise in the high mountain area. IAHS Publ. 256 (Symposium at Birmingham 1999 - Interactions between the Cryosphere, Climate and Greenhouse Gases). 181-191.

Liu, S., W. Sun, Y. Shen and G. Li. 2003. Glacier changes since the Little Ice Age maximum in the western Qilian Shan, northwest China, and consequences of glacier runoff for water supply. J. Glaciol., 49(164), 117-124.

Liu, S. and 8 others. 2004. Variation of glaciers studied on the basis of RS and GIS - a reassessment of the changes of the Xinqingfeng and Malan Ice Caps in the Northern Tibetan Plateau. J. Glaciol. Geocryol., 26(3), 244-252. [In Chinese.]

Mi, D., Z. Xie, X. Luo, Q Feng, M. Ma and D. Jing. 2002. Glacier Inventory of China XI. The Ganga and Indus drainage basin. $\mathrm{Xi}^{\prime}$ an, Xi'an Cartographic Press. [In Chinese.]

Oerlemans, J. 1994. Quantifying global warming from the retreat of glaciers. Science, 264(5156), 243-245.

Oerlemans, J. 2001. Glaciers and climate change. Lisse, A.A. Balkema. 
Paul, F. 2000. Evaluation of different methods for glacier mapping using Landsat TM. In Proceedings of 20th EARSeL Symposium Land Ice and Snow. Dresden, European Association of RemoteSensing Laboratories, 239-245.

Paul, F., C. Huggel, A. Kääb, T. Kellenberger and M. Maisch. 2002a. Comparison of TM-derived glacier areas with higher resolution data sets. In Proceedings of EARSeL-LISSIG-Workshop - Observing our Cryosphere from Space. Bern, European Association of Remote-Sensing Laboratories Special Interest Group Land Ice and Snow, 15-21.

Paul, F., A. Kääb, M. Maisch, T. Kellenberger and W. Haeberli. 2002b. The new remote-sensing-derived Swiss glacier inventory. I. Methods. Ann. Glaciol., 34, 355-361.

Paul, F., C. Huggel and A. Kääb. 2004a. Combining satellite multispectral image data and a digital elevation model for mapping debris-covered glaciers. Remote Sens. Environ., 89, 510-518.

Paul, F., A. Kääb, M. Maisch, T. Kellenberger and W. Haeberli. 2004b. Rapid disintegration of Alpine glaciers observed with satellite data. Geophys. Res. Lett., 31(21), L21402. (10.1029/ 2004GL020816.)

Pu, J., T. Yao and K. Duan. 2003. An observation on surface ablation on the Yangbark glacier in the Muztagata Ata, China. J. Glaciol. Geocryol., 25(6), 280-284. [In Chinese.]

Ren, J., D. Qin and Z. Jing. 1998. Climatic warming causes the glacier retreat in Mt Qomolangma. J. Glaciol. Geocryol., 20(2), 184-185. [In Chinese with English summary.]

Rott, H. 1994. Thematic studies in alpine areas by means of polarimetric SAR and optical imagery. Adv. Space Res., 14(3), 217-226.

Shen, Y., Z. Xie, L. Ding and J. Liu. 1997. Estimation of average mass balance for glaciers in a water shed and its applications. J. Glaciol. Geocryol., 19(4), 302-307. [In Chinese with English summary.]
Shi, Y., Y. Shen and R. Hu. 2002. Preliminary study on signal, impact and foreground of climatic shift from warm-dry to warm-humid in northwest China. J. Glaciol. Geocryol., 24(3), 219-226.

Su, Z., S. Liu and Z. Wang. 1989. Modern glaciers of Mt. Muztag Ata and Mt. Kongur. J. Nat. Resour., 4(3), 241-246. [In Chinese.]

Van de Wal, R.S.W. and M. Wild. 2001. Modeling the response of glaciers to climate change by applying volume-area scaling in combination with a high resolution GCM. Climate Dyn., 18, 359-366.

Wu, G., T. Yao, B. Xu, Z. Li and H. Bao. 2003. Ice-core borehole temperature in the Muztag Ata, East Pamirs. J. Glaciol. Geocryol., 25(6), 676-679. [In Chinese.]

Yang, H. and R. An. 1989. Glacier Inventory of China. Karakorum Mountains (Drainage basin of the Yarkant River). Beijing, Science Press. [In Chinese.]

Yang, J., Y. Ding, R. Chen, S. Liu and A. Lu. 2003. Causes of glacier change in the source regions of the Yangtze and Yellow rivers on the Tibetan Plateau. J. Glaciol., 49(167), 539-546.

Yao, T., S. Liu, J. Pu, Y. Shen and A Lu. 2004. Glacier retreat in high Asia and their impacts to water resource of Northwest China. Science in China (D), 34(6), 535-543. [In Chinese.]

Zhang, S., J. Lu and S. Liu. 2001. Deriving glacier border information on Qinghai Tibet by TM high spectrum image. Geomatics and Information Science of Wuhan University, 26(5), 435-440. [In Chinese.]

Zhang, X. 1980. Recent variation in the glacial termini along the Karakoram Highway. Acta Geogr. Sinica, 35(2), 149-160. [In Chinese.]

Zhen, L., W. Sun and Q. Zeng. 1998. Measurements of glacier variation in the Tibetan Plateau using Landsat data. Remote Sens. Environ., 63, 258-264.

Zuo, Z. and J. Oerlemans. 1997. Contribution of glacier melt to sealevel rise since $A D$ 1865: a regionally differentiated calculation. Climate Dyn., 13, 835-845. 